\title{
The Role of Legal Opinion as Legal Problem Solving Method
}

\author{
Herowati Poesoko ${ }^{1 *}$ and Anak Agung Sagung Laksmi Dewi ${ }^{2}$ \\ 1. Universitas Jember, Jawa Timur-Indonesia \\ 2. Universitas Warmadewa, Denpasar, Bali-Indonesia \\ sandzmunding@gmail.com
}

Published: 28/02/2020

How to cite:

Dixit, P. 2020. The Role of Legal Opinion as Legal Problem Solving Method. Sociological Jurisprudence Journal. Volume 3 Issue 1. Page 1927. https://doi.org/10.22225/scj.3.1.1513.19-27

\begin{abstract}
This study aims to describe Legal Opinion as a Legal Problem Solving Method. The method used in this study is normative legal research; meanwhile the approach used in this study is legal research method. The results revealed that firstly based on legal issues which certainly cannot be separated from the field of law to be studied, while the preparation of legal opinions depends on the depth of knowledge of the legal field what will be found, it is seen in the analysis used in order to find legal problem solving that can be prescription of the legal issue. Therefore, the role of legal opinion in the structure of the layer of legal science can be useful as a method in developing practical law or in developing theoretical law.
\end{abstract}

Keywords: Law, Legal Problem Solving Method, Role of legal opinion

\section{INTRODUCTION}

The background to the problems found in modern society is increasingly pluralistic, amid changes and social dynamics that are not easy to prevent, in turn there is also an increasing need to formulate legal norms into various sets of generally accepted written rules of law (legislation). These written legal rules, among others, function to guarantee stability in legal relations between citizens. Based on this thinking, then basically the rule of law as a system of functional rule of law is a means of anticipation of the possibility of various events in the future. Anticipation is intended to be realized in the form of formulating behavioral models, including typologies of conflicts (disputes) that have the potential to occur in the hope of accommodating a phenomenon that continues to grow and develop. Such a framework is an affirmation that justifies the importance of law as a norm of behavior guidelines. Norms are the institutionalization of conflict typologies as models of behavior as outlined in the rule of law. As it is known, in a practical level, it is certainly not easy to map affinitive behavior models for established norms. However, if in the process of mapping referred to have been understood explicit position as a conclusion: in accordance with or not with the rule of law or substantively there are problems in the rule of law itself, then legal problems arise as a legal issue which at any time becomes news material in various media. Almost every day, whenever and wherever the public is so easy to access various media information, especially information about the law and its problems. It still remains in memory, when the media launched the news about the "legal opinion war" in the Century Bank case, the House of Representatives Banggar case, Testimony of Agus Condro in the election of the Governor of BI, Euforia Macicha Mochtar for the Humanist Constitutional Court's decision, the Simulator Case which dragged Polri officials to the tug of war of the process of investigating Novel Baswedan that sparked opinion of the KPK Police conflict. Even what is currently becoming public opinion is the news regarding the KPK's "ousting" efforts. Such an effort is indeed not new because statistically there have been 14 constitutional tests of the KPK Law in the Constitutional Court, but 14 times also the Constitutional Court declared valid. 
This fact has not only built the attention of public opinion but has also become a commodity in the media business by exploring the diversity of opinions according to their respective perspectives and interests. While the legal opinion as a statement that should be there and needed seems to be unimportant and negated. The irony of this is happening in a country that positions the law as commander in chief. In a normative framework, there is no legal problem that cannot be solved. Some of the problems above become protracted to give birth to new problems because the fundamental factors that should be needed in an effort to give birth to prescriptions as a vehicle for problem solving are not carried out, or even if taken instead are carried out without sincerity. Even the seriousness to solve it is often without being matched by the ability to formulate so that the process and formulation of the legal settlement are carried out partially, impartially, and gradually which becomes even more crucial. In addition to the incomplete influence of the settlement process, the other side of the overlapping factor in the implementation of legal regulations also contributed to the protracted legal problems that never found a solution. Resolving legal issues requires methods, thinking constructs and other academic conventions in accordance with the character of the discipline of law itself, known as Sui Generis. Herein lies the importance of Legal Opinion as a vehicle for prescription to resolve various legal issues (Poesoko, 2012).

Some similar studies with this present study have been carried out by some researchers, such as (Sitorus, 2018) who conducted a research entitled "Legal Opinion and Legal Due Diligence". The results of this study showed that Legal opinion and legal due diligence cannot be separated from the existence of a legal audit and legal reasoning process that is carried out in a convergent manner with material that is so complex because it not only involves the study of legal science but also interdisciplinary science to obtain an overview or information of legal aspects regarding a legal relationship or certain legal events. Furthermore, (Priyono \& Benuf, 2020) also carried out the similar study entitled "The Position of Legal Opinion as a Source of Law". This study aims to explain the position of Legal opinion as a source of law. The results revealed that Legal Opinion has an important position as a rationale expressed by scholars and legal experts in the development of law. Legal opinions or legal opinions from the experts are summarized as a new reference for legal development, can also be in the form of criticism of a policy with the intention of providing advice or input, in order to have permanent legal force, this legal opinion must be contained in a judge's decision. This means that legal opinion is a source of law that can be categorized as a doctrine, and will have binding legal force if it is a judge's decision. Based on the background and the latest related study above, on this occasion, this study aims to describe Legal Opinion as a Legal Problem Solving Method.

\section{METHOD}

The method used in this study is normative legal research; meanwhile the approach used in this study is legal research method which describes legal opinion as a legal problem solving method. The data used in this study is secondary data in the form of literature and related legislation, in this case is legal theory. This study described the essence of legal opinion.

\section{III.RESULT AND DISCUSSION}

Based on the study that has been carried out, thus it obtained the results of the study that can be described in the following discussion.

\section{Legal Opinion Structure in the Layers of Law}

Before explaining the essence of Legal Opinion, it is necessary to know the structure of Legal Opinion in the layers of legal science. Law is a science and belongs to the group of normological practical sciences. This practical science is a field where various sciences meet and interact (converge). As a normological practical science, the final product is a problem solving that is scientifically (rationally) accountable (Peursen, 1990). As said above, legal science as well as Sui Generis Science means to have special characteristics that are different from other sciences because of: Normative Character of Legal Studies; Legal Science Terminology; Types of Legal Studies and Layers of Legal Studies (Hadjon \& Djatmiati, 2005).

The Legal Layer according to J. Gijssels and Marck van Hoecke in (Tutik, 2012) describes the legal layer (trappen van de Rechtswetenschap): 


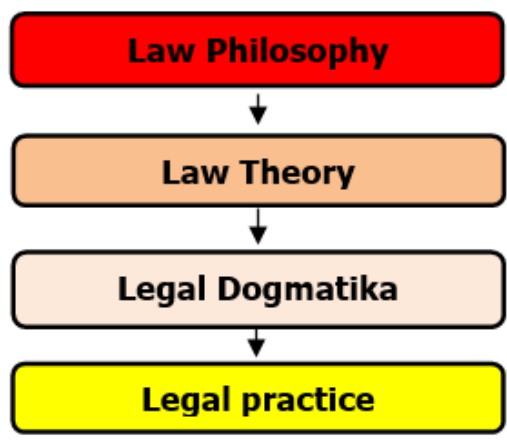

Figure 1

Layers of Legal Studies According to J. Gijssels \& Marck van Hoecke (Tutik, 2012)

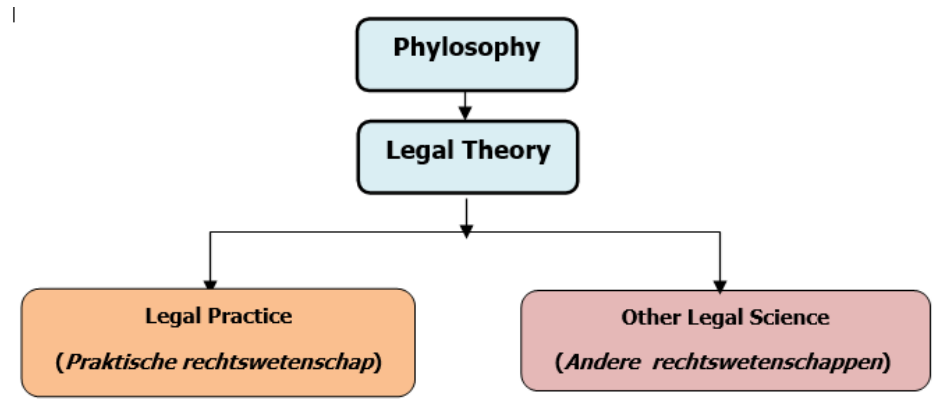

Figure 2

Layers of Legal Studies According to H.P.H Visser Thooft (Sidharta, 2007)

The dogmatic of law, legal theory, and philosophy of law must ultimately be directed towards the practice of law. There are two main aspects of legal practice, namely the formation of law and the application of law, which some legal experts also interpret as legal discovery. In contrast to the opinion of H.P.H Visser Thooft from the standpoint of the philosophy of science describes the layer of legal science as follows:

Refer to the Pictures of J. Gijssels and Marck van Hoecke by comparing the images of Visser, the question of whether legal doctrine can be interpreted as practical legal science (trappen van de Rechtswetenschap) based on Meuwissen's opinion "The last characteristic relates to the practical meaning of the Doctrine of Law ultimately related to the practical application of law" (Sidharta, 2007) concluded that legal dogmatic (positive law) is practical law, whose function of practical law is problem solving. Thus, legal doctrine as a practical legal science is the goal of legal problem solving.

According to Paul Scholten, as long as people do not interpret ars as a skill or technique, but rather give a form to blurred images, make it crystallize into law, so a creation of a form that can be called art, (ars) is very similar to science (Sidharta, 2005). According to Hugo de Groot and Rangers Hora Siccama rejects the notion that the teachings of law or legal doctrines are sciences, but they are art based on science, based on knowledge of social relations that are always developing. The art of law that is not based on science will cease as art. Therefore, the art of law, including justice, the formation of laws and doctrinal jurisprudence, is not possible without knowledge of economic relations, and increasingly complex societies that must be regulated by law, (Apeldoorn, 1954). Ars are needed by jurists to compile legal opinions as output from legal problem solving steps. Ars in question are legal reasoning or legal argumentation, which is essentially giving reason. The polemic phenomenon from the legal implication itself has very wide access in the community so that a concrete and actual explanation is needed to eliminate the topic of problems that become gossip in the community as written above, therefore we need a Legal Opinion as one method of solving legal problems.

Etymologically Legal Opinion from Latin is referred to as Ius Opinio, means Ius $=$ law, and Opinio $=$ Opinion, which in the Continental European legal system is known as Legal Critics, while the Common Law (Anglo Saxon) legal system is called Legal Opinion. Basically, legal opinion is the result of legal reasoning by the bearers of law by giving prescriptions to answer legal issues.

The description above is understood that the legal doctrine is a practical law, which involves two main aspects of legal practice, is the Formation of Law and Application of Law that needs to be elaborated on the structure of legal opinion in the realm of legal science. Whereas the application of law while legal experts provide the term with legal discovery.

Some terms in the discovery of law are often associated with legal discovery, namely:

Rechtsvorming (the formation of law), which is to formulate general rules for everyone. Typically carried out by legislators. Judges are also possible as a judge made law if the decision becomes a permanent jurisprudence (vaste jurisprudence) followed by the judges and is a guideline for the legal community in general. 
Rechtstoepassing (application of law), i.e. Applying abstract legal regulations to events. For this reason a concrete event must be made a legal event first so that the legal regulations can be applied.

Rechtshandhaving (implementation of law), can mean to run the law whether there is a dispute / violation or without dispute.

Rechtschepping (creation of law), means that the law is completely non-existent then created, that is, from nothing to being.

Rechtsvinding (legal discovery or law making - English), in the sense that not the law does not exist, but the law already exists, but still needs to be explored and discovered. The law is not always a rule (das sollen) whether written or not, but it can also be a behavior or event (das sein). From this behavior, law can actually be extracted or found (vide article 28 of Law No. 4 of 2004). In that behavior there is a law. Therefore the term legal discovery is felt more quickly (Sutiyoso, 2006).

Some terminology of legal invention mentioned above term rechtsvinding (legal discovery) with rechtsvorming (the formation of law) can lead to polemic in its use. Nevertheless both have differences between one another. The term rechtsvinding in the sense that not the law does not exist, but the law already exists, but still needs to be explored, sought and found, while the term rechtsvorming in the sense of the law does not exist, therefore there is a need for legal formation, so that there is the creation of law as well (Sutiyoso, 2006). The function of rechtsvinding is to find concrete norms to be applied to related legal facts. Understanding rechtsvinding in Indonesian as a legal discovery (literal translation), can be misleading.

Understanding of some of the terms about the discovery of the law mentioned above will be understood based on the context of the momentum that determines 'when' the term is used. In analyzing cases / disputes, that is to say, when the stages of resolving legal problems include Rechtsvorming (legal formation), Rechtstoepassing (application of the law), Rechtshandhaving (implementing the law), Rechtschepping (legal creation), Rechtsvinding (legal discovery or law making - English).

Furthermore, it rests on the legal layer according to J. Gijssels and Marck van Hoecke as well as the Legal Science layer from the point of view of the philosophy of science according to H.P.H Visser Thooft, it can be described the structure of the Legal Opinion in Legal Studies, as illustrated below:

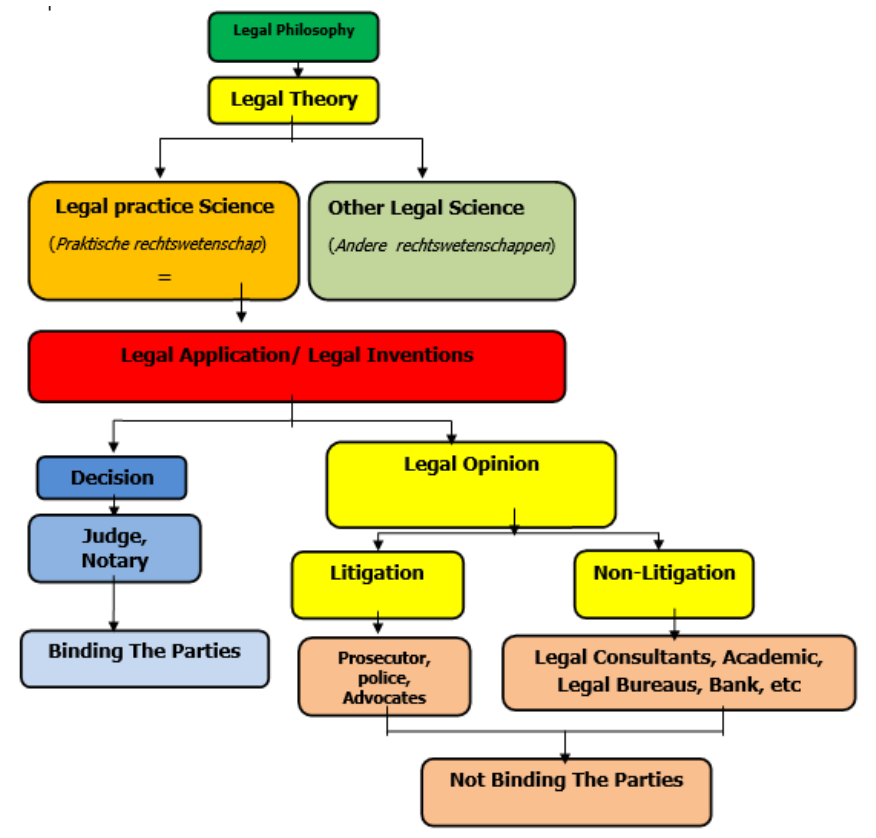

Legal Opinion is carried out by a legal scholar whose legal profession is often referred to as the legal profession. Legal Practitioners (Judges, Prosecutors, Advocates), Notaries, Legal Consultants and Academics (as legal scientists). Legal Banking is even possible, a part of the government law firm and so on. Therefore, with the character of such jurisprudence, J.J.H Brunggink said: "It is impossible for 
someone who is not a jurist to understand well arest Hoge Raad. He must understand the language of law and legal concepts ". This shows that the science of law is a practical legal science that has the nature of Sui Generis. Furthermore, by looking at the layer of legal science, legal opinion is one of the main elements of practical legal science (legal doctrine) in the realm of application/legal discovery.

As the essence of Legal Opinion, the aim is to solve and solve legal problems (problem solving). The problem arises as a result of social interaction as community activities carried out by individuals or Legal Entities (legal subjects), which are inseparable and the enactment of the law in social interactions, such as the existence of legal relations, legal actions, legal events that are included in the type Civil Law, Commercial Law, Business Law, Agrarian Law, Criminal Law or State Administrative Law.

Human activities relating to the existence and entry into force of law in society, in reality everyday life is concretely a legal development, is what Meuwissen calls rechtsbeoefening (law enforcement), and one of the keys that is centered in "Vijf Stellingen over Rechtsfilosofie" is the concept of "rechtsbeoefening" here translated with the words "legal bearers" (Sidharta, 2007). These activities include the activities of forming, implementing, implementing, discovering, researching, and systematically studying and teaching the applicable law. Law enforcement can be divided into practical law enforcement and theoretical legal development (Sidharta, 2007).

Practical law enforcement is an activity relating to the realization of the law in the reality of daily life in a concrete way. Practical law enforcement includes activities such as law formation, legal discovery and legal aid. The theoretical legal development of law is the activity of the intellect to gain intellectual mastery over the law or an understanding of the law scientifically, that is methodically-organized, methodologically-logic-organized rationality (Sidharta, 2007). According to Meuwissen, practical legal development or legal handling in reality of life truly recognizes three forms: legal formation, legal discovery, and legal aid. Here, especially Dokmatic Law shows its practical importance directly.

If it is searched Legal Opinion indeed includes practical legal development, but whether in the realm of legal discovery or application of the law. Because legal discovery is a process of concrete jurisdictional decision-making activities that directly lead to legal consequences for an individual situation (judges' decisions, decrees, notarial deed making and so on). While the adoption of law (Rechtstoepassing) is the application of abstract legal regulations to events, for this reason concrete events must be made legal events in advance so that the legal rules can be applied. But in the implementation of legal discovery and application of the law the similarity is in terms of the method while the difference is at the end of the analysis, the legal process finding is the final decision, which binds the parties to the dispute while in the application of legal opinion (legal opinion) is a legal opinion with the aim of providing guidelines for non-binding clients for the parties to the dispute.

\section{Determine Legal Issues}

Legal issues can actually arise at the level of legal doctrine, legal theory, and philosophy of law and are even possible in case positions involving all layers of the science of law. The formulation of legal issues becomes the central point of legal studies, because sharp legal issues will provide direction in answering questions on the legal issues they present. The legal opinion writer must be careful and critical in determining the legal issues because legal issues in general are in the form of something related to relevant legal provisions and legal facts that are faced. Therefore, the legal opinion writer is able to address whether the position case presented is really a legal issue or not. Concrete facts regarding this matter, for example, are normatively determined in Law no. 1 of 1974 concerning Marriage Article 2 paragraph 1, that a marriage is lawful if it is done according to the law of each religion and its beliefs. The problem is if a person does not follow the religion set by the government, is the marriage conducted according to the law?

The latest legal issues occur in the field of labor law. The ILO, through its convention No.189, stated that there were guarantees of protection for domestic workers. This convention raises new legal issues in Indonesia considering that our country does not yet have laws that specifically regulate and provide protection to domestic workers, so the existence of domestic workers today does not yet have protection that provides legal certainty. The labor law which has been used to provide protection for workers or workers, is Law No. 13 of 2003 concerning Manpower. The problem is whether domestic workers are categorized as Labor or Workers? 
To answer these two legal issues, certain concepts and methods are needed as a rule in the discipline of law according to the sui generis character possessed by legal experts. Therefore it is not excessive if someone who is not a legal expert might not be able to raise legal issues.

\section{Develop Legal Opinion}

The first thing to do in preparing Legal Opinion is to describe the positive law and at the same time systematize the positive legal system. In terms of describing positive law (exposure to the rule of law) whose task includes the content and structure of positive law, but before looking at the contents and structure of positive law first, the position of the case includes which type of law, what is civil law, business law, agrarian law, state administrative law, criminal law or the presence or absence of a point of contact between these types of law. In legal presentation, in the context of positive legal description what happens is to determine the content of the rule of law as precisely as possible, the matter of determining the contents of the rule of law means determining what happens the legal method. Exposure to the rule of law will depend on the theory of interpretation adopted by legal scientists. Because in the development of jurisprudence not only explains how the rule of law can be interpreted, but also determines the choice of the various possible alternative meanings in an argumentation. That is, the legal scientist in his work must determine how the rule of law should be interpreted, for example the case of procurement of goods by government agencies, even though the procurement of goods departs from treaty law, in the case position there is a point of contact with state administrative law and special criminal law.

As for the systematization and structuring process, a number of general rules and legal concepts and legal concepts are formed or formulated. The formation and existence of a set of general rules and juridical concepts is needed to enable or facilitate the mass processing of legal material in the systematization and structuring of the legal material. The intended juridical concept is a concept which is a component of the rule of law, specifically the concept used to describe the fact situation in relation to the provisions of the law which are explained by interpretation.

Furthermore, in systematizing a positive legal system there are 4 principles of reasoning, namely:

Derogation rejects a rule that is contrary to higher rules;

Non-contradiction must not state whether or not an obligation is related to a similar situation;

It is assumed that there is a logical relationship between the two rules in the relationship between the higher and the lower rules;

The exclusion of each legal system is identified by a number of laws and regulations (Hadjon, 1994).

Because in the practice of law, especially in the application of law, it is often found that laws and regulations include legal vacuum, (leemten in het recht), norm conflicts (antinomy) and vage norms and inconsistencies. Some facts as a fact that emphasize the problem of the application of these laws and regulations include: the regulation of Domestic Workers. In the sense of the word even though the ILO has issued its Convention No.189 on the Protection of Household Workers, the benefits of the ILO product cannot be felt immediately, given that until now our country does not yet have a rule of law that specifically provides legal certainty for the protection of domestic workers. This is a fact of legal vacuum.

The other side is also often encountered by conflicting norms. For example the execution of the Execution Parate as regulated in Law No. 4. In 1996 concerning Mortgage Rights and Land Related Items. In Article 6 it is stated that "if the debtor fails to promise, the first mortgage right holder has the right to sell the object of the mortgage right on his own power through a public auction and to repay the debt from the proceeds of the sale." In terms of substance, Article 6 which gives the rights to the holder of the first mortgage to sell the mortgage on his own power through an auction is called the Parate Executie. But if it is related to the explanation of Article 14 in the same law: '........ so that if the debtor fails to promise, it is ready to be executed as a court decision which has obtained permanent legal force, through procedures and by using the excuse parate institution in accordance with the Civil Procedure Code ". This means based on the Elucidation of Article 14. If the Former of Law No. 4. In 1996, Parate Executie must take the application to the court for a decision. Such legal facts are indicative of norm conflicts. Considering there are two conflicting executions. 
Whereas understanding of blurring norms can be seen from the concept of marriage based on Law No.1 of 1974 concerning Marriage. Article 2 paragraph (1) is stated thus: "a marriage is legal if it is carried out according to the law of each religion and its beliefs". The ambiguity of the norm lies in the interpretation of the word belief intended in the provisions of article 2 paragraph (1). There are two interpretations in this regard. First, the word belief is interpreted as a belief in the substance of the teachings in the internal of each religion. Opinion Both words of belief are understood as beliefs that are separated from the category of the religious system in Indonesia which do not belong to one of the six official religions.

One more thing about norm inconsistencies. In Law No. 20 of 2003 concerning National Education System Article 21 was mentioned:

Higher education institutions that meet the establishment requirements and are declared entitled to hold certain educational programs can provide academic, professional or vocational degrees in accordance with the educational program that they hold.

Academic, professional or vocational degrees are only used by graduates from tertiary institutions who are declared entitled to give academic, professional or vocational degrees.

Based on the provisions above it can be understood that an academic degree is always attached to an individual wherever located in the realm of administration. However, in practice the process of obtaining a KTP or similar identity card, the existence of an academic degree is actually negated so that each resident's KTP does not have an academic degree. This fact is an indication of legal inconsistency.

\section{Analysis of Legal Issues}

Analysis of legal issues is an "open system", which means that the rule of law and decisions must be considered in a relationship and also that legal norms rest on the principle of law and behind the principle of law can be systematized by other symptoms. In analyzing legal issues, several methods can be used, including positive legal interpretation, legal construction, legal arguments based on the logic of induction and / or deduction in law. That from the legal facts that have been described above can be analyzed using the method as described below. Legal science recognizes various methods of interpretation that have a hermeneutic character. Legal scientists must be able to take responsibility for each particular method of interpretation selection. Legal interpretation method (Hadjon, 1994), such as:

Grammatical Interpretation, means a legal term or a part of a sentence according to everyday language or legal language;

Systematic interpretation, with the starting point of the system of rules means a legal provision;

Wets-en rechtshistorisch interpretatie, tracing the intention of establishing the Act is a "wetshistorische interpretatie" in terms of trying to find answers to a legal issue by tracing legal developments (rules) called "historche interpretatie";

Interpretation of comparative law seeks to resolve a legal issue by comparing various legal systems;

Interpretation of anticipation answers a legal issue by basing it on rules that do not yet apply;

Teleological interpretation, each interpretation is basically teleological.

The legal construction method (exposition method) is meant is a method for explaining words or forming an understanding (law) not for explaining goods, meaning that the method is a tool used to arrange legal material, which is carried out systematically in the form of language and terms right. Although the purpose of the legal construction is the judge's decision, in making a legal opinion, especially when analyzing the legal issues, this legal construction can be used. According to Rudolph von Jhering as quoted by Achmad Ali in (Sutiyoso, 2006), there are 3 (three) main requirements for legal construction, namely:

Legal construction must be able to cover all areas of positive law;

In making construction there must not be a logical contradiction in it or it cannot refute itself;

The construction reflects the beauty factor, that is, construction is not something made up and construction must be able to give a clear picture of something. 
In the construction of law consists of the Analogy Method (Argumentum Roleogiam), Method A Contrario (Argumentum a contrario), and the Rechtsvervijning Method (narrowing of law), which has the following meanings:

Analogy Method (Argumentum role alogiam) The analogy method means expanding legislation that is too narrow in scope, then applied to events that are similar, similar or similar to those regulated in the law.

Method A Contrario (Argumentum a contrario) A Contrario method is a way to explain the meaning of the law based on the opposite understanding of the concrete events that are faced with the events set out in the law.

Method (narrowing of law) this method aims to concretize or narrow a rule of law that is too abstract, broad, and general, so that it can be applied to a particular event.

Based on the explanation above, then in an effort to improve the quality and commitment of law enforcement to civilize Legal Opinion as a means to resolve legal issues, of course it is necessary to have a common view of the importance of Legal Opinion and its development methods in the academic and practical realms, including the consistency of its use. Analysis of legal problem salving is certainly not limited to the interpretation and construction of law but can also use the principles of law, legal theory and even legal reasoning and legal logic. But this commitment is still limited to desire. Imagine, in fact there are some findings that need to be informed, among others: First, not all law higher education in Indonesia places Legal Opinion as an integrated course in the law faculty curriculum. Legal Opinion is no more a foreign term, let alone an understanding of the substance and functional aspects of its use.

Students are not sufficiently equipped to understand the components as a vehicle for giving birth to the much needed prescriptions, even though the level of education of Strata One who is struggling in the realm of legal doctrine is absolutely required to have the skills to make or compile Legal Opinion. More than that, the Legal Service Center, the Legal Aid Bureau as an institutional unit in the Faculty of Law that functionally runs public services in the field of law becomes a 'poor way' to build legal prescriptions as solutions needed by people who need services. Second, the impact of the legal higher education system that does not accommodate Legal Opinion in turn gives birth to legal practitioners (judges, police, lawyers, bureaucrats from the law to legislation) who are unfamiliar to various methodical media in order to carry out their profession. It is no exaggeration to say that the legal practitioners' limitations on Legal Opinion will psychologically give birth to insecurity so that it does not rule out the possibility of carrying out the practice of anorma in enforcing norms. Incorrect application of the law, it is even possible that there is no room for people whose interests have been harmed to obtain legal protection because the regulation does not have a sense of justice or less useful because it is due to lack of legal certainty.

\section{IV.CONCLUSION}

Based on the objectives and the results of the study that has been described above, thus it can be concluded that, firstly based on legal issues which certainly cannot be separated from the field of law to be studied, while the preparation of legal opinions depends on the depth of knowledge of the legal field what will be found, it is seen in the analysis used in order to find legal problem solving that can be prescription of the legal issue. Therefore, the role of legal opinion in the structure of the layer of legal science can be useful as a method in developing practical law or in developing theoretical law.

\section{REFERENCES}

Departemen Pendidikan Kebudayaan, Kamus Besar Bahasa Indonesia - Cetakan kedua, Jakarta : Balai Pustaka, 1989

Hadjon, P. M. (1994). Pengkajian Ilmu Hukum Dogmatik (Normatif). Y uridika, 8(1). Retrieved from https://ejournal.unair.ac.id/YDK/article/view/5762

Hadjon, P. M., \& Djatmiati, T. S. (2005). Argumentasi Hukum. Retrieved from https://ugmpress.ugm.ac.id/id/ product/hukum/argumentasi-hukum

Peursen, C. A. Van. (1990). Wetenschap En Werkelijkheid, Juga Fakta, Nilai, Peristiwa. Tentang hubungan antara Ilmu Pengetahuan dan Etika, diterjemahkan oleh A. Sonny Keraf. Retrieved from http://www.lib.ui.ac.id/ 
detail?id $=1471$

Poesoko, H. (2012). Dinamika Hukum Parate Executie Obyek Hak Tanggungan, Cetakan Kedua. Yogyakarta: Aswaja Pressindo.

Priyono, E. A., \& Benuf, K. (2020). Kedudukan Legal Opinion sebagai Sumber Hukum. Jurnal Suara Hukum, 2 (1), 54-70. Retrieved from http://dx.doi.org/10.26740/1.jsh.2020.2.1.7034

Sidharta, A. (2005). Struktur Ilmu Hukum. Bandung: Alumni.

Sidharta, A. (2007). Pengantar dalam Meuwissen Tentang Pengembanan Hukum Ilmu Hukum Teori Hukum, dan Filsafat Hukum. Bandung: Refika Aditama.

Sitorus, S. (2018). Pendapat Hukum (Legal Opinion) Dan Uji Kepatutan Dari Segi Hukum (Legal Due Diligence). Jurnal Hikmah, 15(2), 166-178. Retrieved from http://jurnalhikmah.staisumatera-medan.ac.id/index.php/ hikmah/article/download/36/36

Sutiyoso, B. (2006). Metode Penemuan Hukum. Yogyakarta: Universitas Islam Indonesia Press.

Tutik, T. T. (2012). Hakikat Keilmuan Ilmu Hukum Ditinjau Dari Sudut Filsafat Ilmu Dan Teori Ilmu Hukum. Mimbar Hukum, 24(3), 443-458. Retrieved from https://doi.org/10.22146/jmh.16114

Undang-Undang No.17 Tahun 2005 tentang Rencana Pembangunan Jangka Panjang Nasional Tahun 2005-2025Lampiran Bab IV tentang Arah Tahapan dan Prioritas Pembangunan Jangka Panjang Tahun 2005 - 2025 IV.1.2 Mewujudkan Bangsa yang Berdaya Saing - Huruf E Reformasi Hukum dan Birokrasi. 